\title{
From debt to eternity
}

\author{
Sinclair Davidson ${ }^{1}$
}

\section{Abstract}

This paper documents the increase in Australian public debt since 2007. In that year, gross public debt had a face value of $\$ 55$ billion, while net debt was negative. It is not surprising that governments have since resorted to public debt to respond to a series of shocks to the Australian economy. What is surprising is that Australian policymakers have abandoned the old-time fiscal religion'.

Speaking on Budget Night, 11 May 2021, Australian Treasurer Josh Frydenberg made the following statement:

Net debt will increase to $\$ 617.5$ billion or 30.0 per cent of GDP this year and peak at $\$ 980.6$ billion or 40.9 per cent of GDP in June 2025 .

This is low by international standards. (Frydenberg, 2021)

The comparison 'low by international standards' is meant to be reassuring. And, superficially, these statements are true. As the economic forecasting stood on that day, net debt was expected to reach a particular level and, by international standards, that level, as a percentage of GDP, was low. Yet the statement is entirely misleading. Australian government debt will not be paid by the international community. How much debt the Australian government incurs is a matter for Australian taxpayers-future taxpayers at that-and international comparisons provide no information as to the burden that debt places on Australian taxpayers.

1 RMIT University; sinclair.davidson@rmit.edu.au. The author thanks Darcy Allen and Aaron Lane for comments that have improved the quality of the paper. 
Australian government debt is high by Australian historical standards. Certainly, it is high over the period since 1970. This paper documents the growth of Australian government debt over the period 1970-2025 (the end of the current budget forecast period). It also addresses the notion that debt is currently 'cheap'. It is true that interest rates are low and interest payments as a percentage of government spending are low by historical standards. But that is not the burden imposed by public debt.

Following the work of James Buchanan, the argument is made that public debt imposes a burden on future generations and, in particular, future taxpayers. This is particularly problematic as Australia is heavily reliant on direct taxation and the personal income tax is itself highly progressive, with a small number of taxpayers paying the lion's share of the tax.

\section{The magnitude of Australian debt}

Figure 1 shows the magnitude of Australian Commonwealth debt since 1970-71. The data are captured from the 2021-22 budget papers and show the face value of the debt. This is the more appropriate value to show (as opposed to the market value of the debt) as it is this amount that must ultimately be repaid. The figure also shows the net debt data.

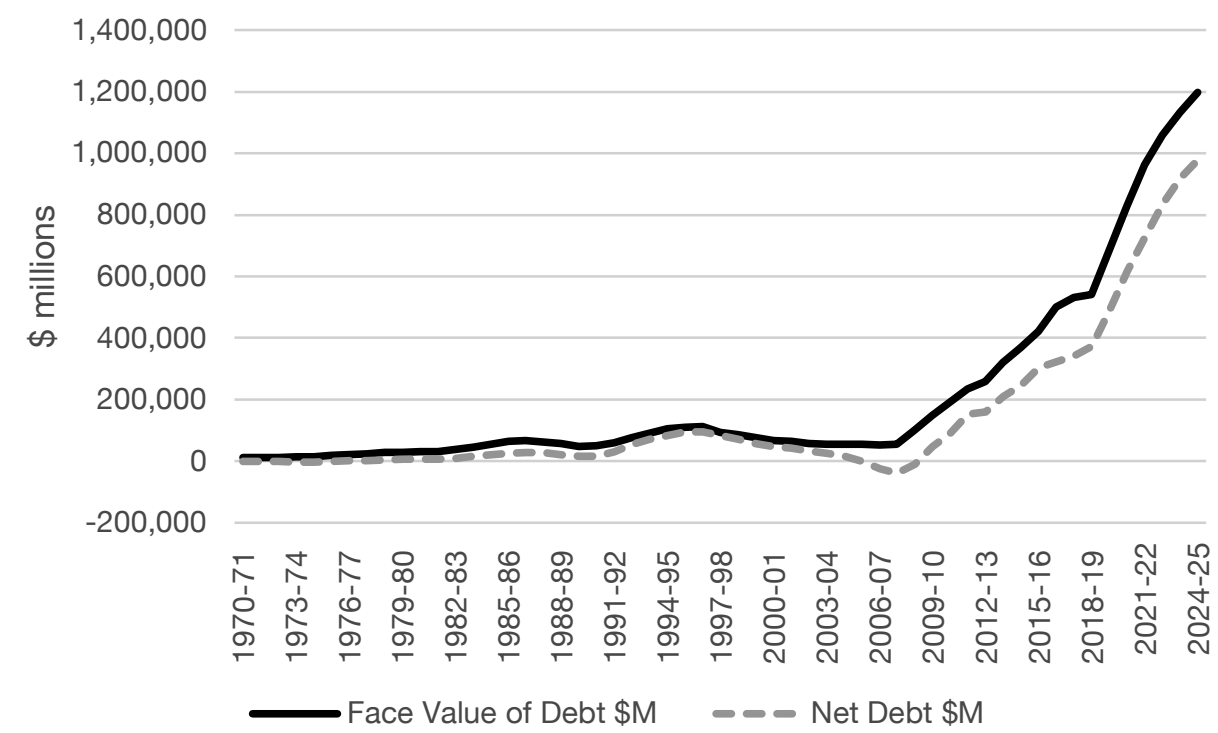

Figure 1. Commonwealth debt

Source: Budget papers (various years). 


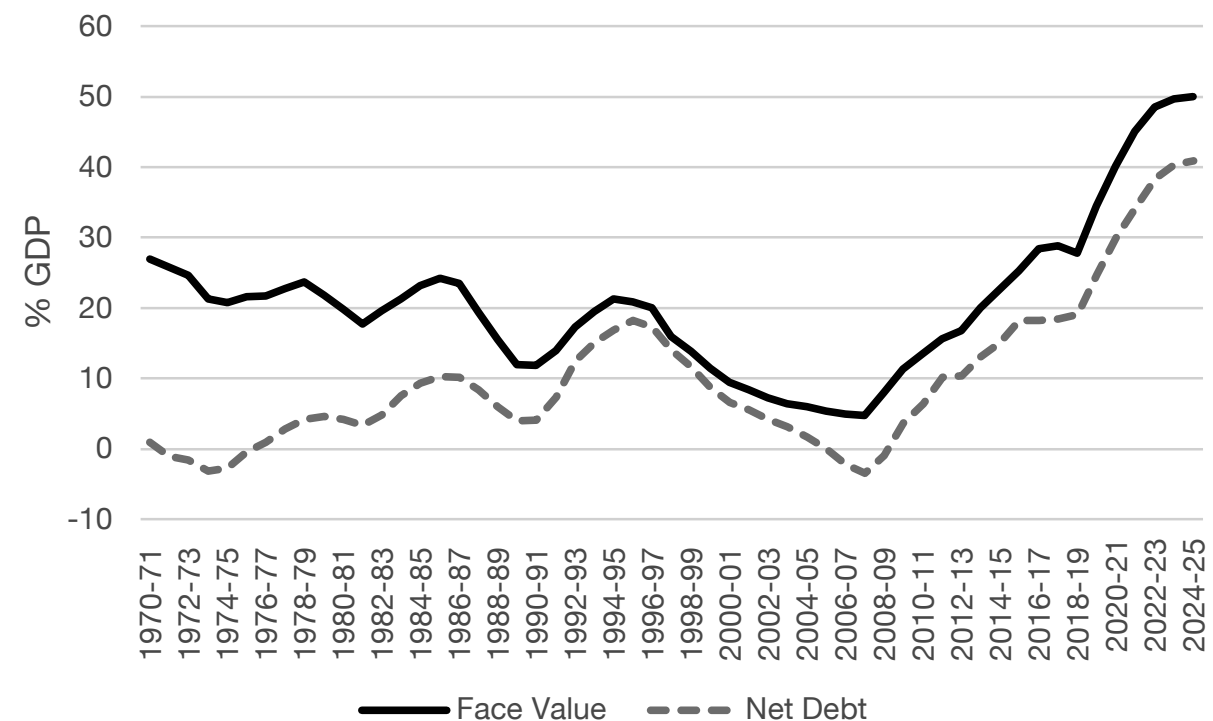

Figure 2. Commonwealth debt as a percentage of GDP

Source: Budget papers (various years).

Commonwealth debt might be 'low' by international standards, but it is not low as measured over the 55 years reported in the Budget papers. There is a very clear turning point in the data: before the 2007-08 Global Financial Crisis (GFC), Commonwealth debt was well below $\$ 200$ billion. Commonwealth debt has dramatically increased since the GFC and appears to have increased again since the 2018-19 financial year. This pattern is entirely explained by shocks to the economy. After the GFC, the government increased spending to stimulate the economy. Similarly, in the summer of 2019-20, Australia experienced devastating bushfires and was impacted by the Covid-19 pandemic after March 2020. In the 2019-20 budget, the federal government expected net public debt to be $\$ 360$ billion in that year. In the 2020-21 budget, however, net public debt for 2019-20 was reported to be $\$ 491$ billion (see Table 1).

Some readers may argue that the dollar value of debt is an inappropriate measure; the economy is much larger now than it was in the early 1970s and inflation has eroded the value of money over that 50 -year period. Rather, it could be argued that we should examine debt as a percentage of GDP. That exercise is shown in Figure 2.

Again, it is the case that Commonwealth debt is not low by historical standards. The pattern of the data reveals that Australia is even more indebted now than it was in the 1970s and 1980s. 
AGENDA, VOLUME 28, NUMBER 1, 2021

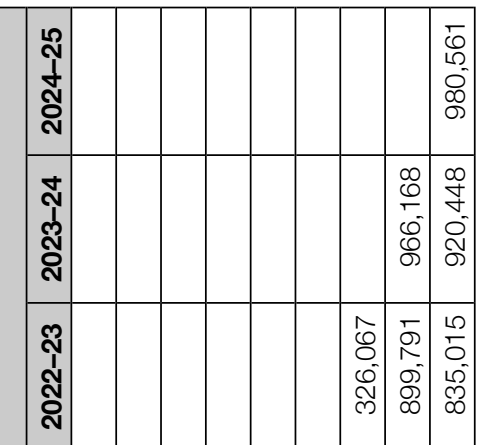

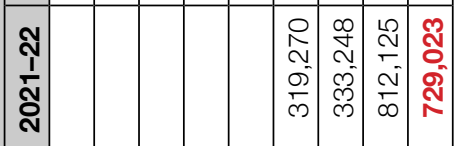

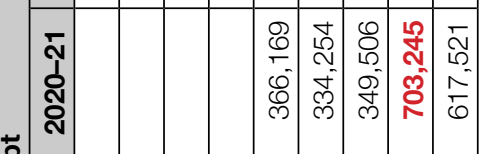

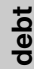

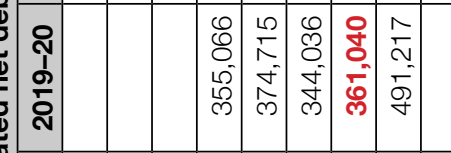

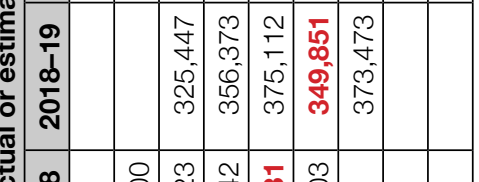

赵

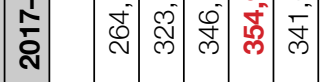

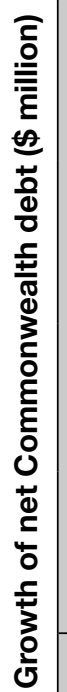

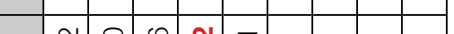

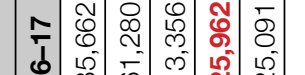

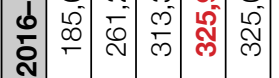

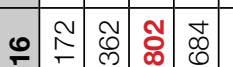

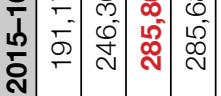

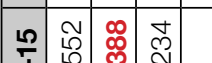

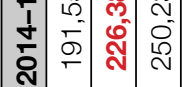

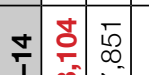

类

-

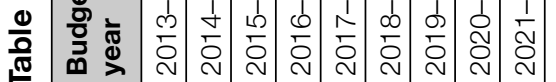

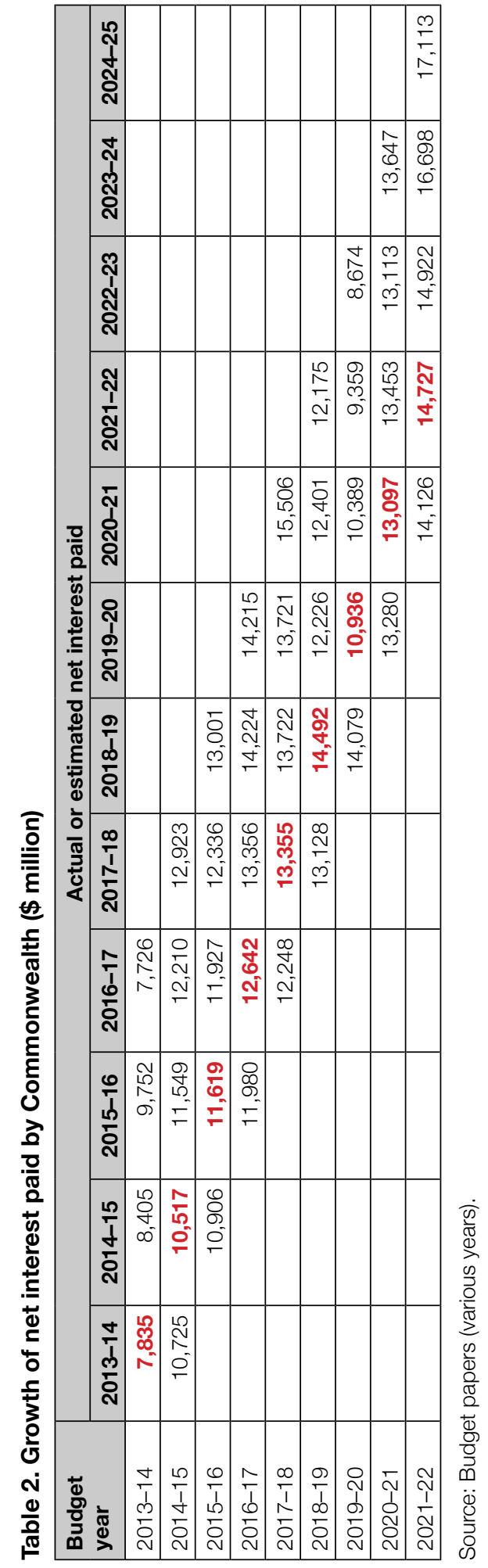


Table 1 shows the evolution of expected net debt compared with the actual net debt reported in any year. The data reported in the rows are taken from the budget papers of that year and the data in the columns are expected net debt for the year being reported. The trailing figure is the realisation of net debt in any given year. For example, the 2020-21 budget papers forecast a net debt of $\$ 703.2$ billion for that year; the figure immediately below it, reported in the 2021-22 budget, shows the actual figure to be $\$ 617.5$ billion. The 2021-22 budget papers forecast the 2021-22 net debt to be $\$ 729$ billion and \$980.6 billion in 2024-25.

Table 2 shows similar data for the evolution of expected net interest payments compared with the actual net interest payments. In 2020-21, the budget papers forecast a net interest payment of $\$ 13.1$ billion for the 2020-21 financial year. The 2021-22 budget papers revealed the actual payment to be $\$ 14.1$ billion.

The interesting observation is that while the forecast net debt (shown in Table 1) was some $\$ 85.7$ billion less than initially forecast, the net interest payment was $\$ 1$ billion more than forecast. The other interesting observation is that net debt has increased by a factor of about 3 , while net interest payments have only increased by about 30 to 40 per cent.

That observation may explain the increase in the use of debt-or at least the reluctance to pay off debt after 2013 until 2019; it may be that policymakers believe that debt is 'cheap'. Chris Richardson of Deloitte Access Economics has made that argument: 'Never in the 2000 years of recorded history of interest rates has it been cheaper for governments to borrow' (Cranston, 2020). If debt is cheap then perhaps it is a sensible argument to borrow to continue spending at higher levels rather than either cut spending or increase taxation.

Figure 3 shows that argument in stark terms. The implied interest rate is the (gross) interest paid dividend by the face value of the debt expressed as a percentage. Interest percentage spending is the (gross) interest paid divided by government spending. Interest expenditure as a percentage of overall government spending is low by historical standards at less than 4 per cent. Similarly, the implied interest rate is also low by historical standards. 


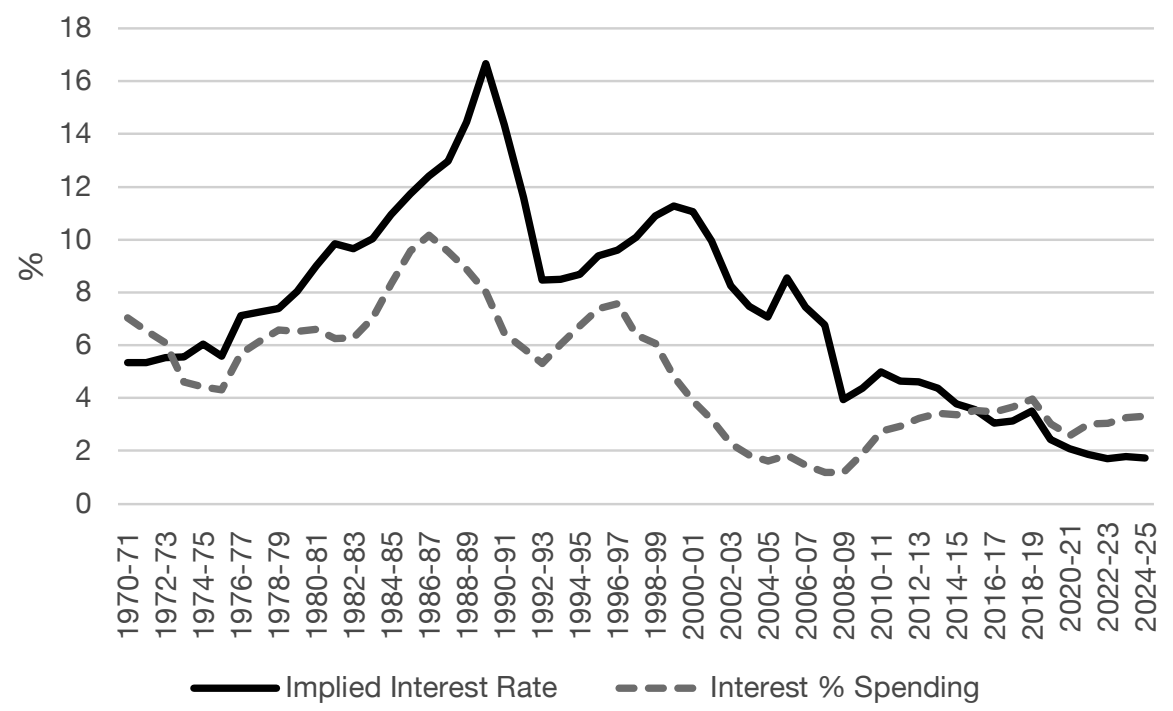

Figure 3. Implied interest rate and interest paid as a percentage of spending Sources: Budget papers (various years) and author calculations.

\section{The burden of public debt}

Public debt—just like private debt—must ultimately be repaid with interest. This is trivially true. To be sure, lenders do not want borrowers to repay their debts; after all, they earn interest while the debt is outstanding. But they do want borrowers to be able to repay their debts.

Australian governments do not intend to run budget deficits in perpetuity, nor do they intend to not pay down public debt (but see the discussion below). There is little doubt the Australian Government has the capacity to repay its debts. Australian government debt is highly rated by the international ratings agencies (triple-A rated by all three international ratings agencies) and holders of Australian government debt are exposed to little, if any, sovereign risk.

The public debt burden is not the interest payments on the debt. Those payments simply represent the compensation that lenders require to hold the debt. Rather, the burden of public debt is the future deadweight costs of taxation that are imposed to pay debts incurred in the present. This argument was articulated by James Buchanan (1999a): debt is paid by 'future generations'. Future taxpayers bear the burden of paying for expenditure that has occurred in the past. The consequences of that outcome-further articulated in Buchanan and Wagner $(1967,2000)$-are 
that current generations will incur greater levels of public spending in the present associated with higher levels of debt and lower levels of current taxation to finance that level of public spending.

There are at least two counterarguments that can be levied against Buchanan's view. First, current generations may deploy debt finance to invest in productivityenhancing activity that generates economic growth in excess of what otherwise would have been the case, and consequently future generations enjoy an inheritance rather than a cost. This is an empirical claim. Bear in mind, however, that future opportunity costs are subjective and cannot be known in the present (on this point, see Buchanan, 1999b).

The second counterargument relates to Ricardian equivalence. Taxpayers in the present-well aware they face a higher tax burden in the future-save now to offset the public debt (for a modern analysis of Ricardo's original argument, see Barro, 1974). Buchanan (1976) argues that Barro (1974) constructs a special (and unusual) case for his argument and that his analysis is inconsistent with observed behaviour, while Buchanan and Wagner (2000) argue that Ricardian equivalence can only hold in a community of homogeneous decision-makers with perfect knowledge.

\section{Why does this matter?}

To the extent that increased public debt is high and that it imposes a burden on future generations, this is an increased burden on future taxpayers. The fact is the Australian tax base is quite narrow. The Henry Review (Henry, 2010), for example, reported that while Australian governments (federal, state and local) levied some 125 different taxes, 90 per cent of all tax revenue was raised by just 10 taxes. Of those 10 taxes, the personal income tax and the company income tax raised the lion's share of revenue. The Henry Review also provided empirical estimates of the deadweight costs associated with the company income tax to be 40 per cent and the personal income tax to be 24 per cent. Furthermore, Australia has a high reliance on these direct taxes compared with most Organisation for Economic Co-operation and Development (OECD) economies.

This implies that even though the face value of Australian debt might be 'low' compared with other economies, or even that the debt as a percentage of GDP is 'low' compared with other economies, the actual burden of that debt might be high.

The analysis is further confounded by the progressive nature of the Australian personal tax system. Davidson (2009) reports that the top 25 per cent of income earners paid 66 per cent of all net personal income tax in 2006-07. Davidson (2009) sourced his data from the Australian Taxation Office (ATO) Taxation Statistics; using that same data source and investigating the latest available data 
(2018-19), that share is now 67 per cent. Similarly, the Australian company taxwhile not progressive-is mostly collected from a small number of highly profitable companies. Davidson and Heaney (2012) report that 0.5 per cent of companies liable for the Australian company tax pay 76.26 per cent of net company tax. Those data related to the 2007-08 tax year and, again, were calculated from data provided by the ATO Taxation Statistics. A similar statistic for the 2018-19 tax year is that 0.3 per cent of companies liable for the Australian company tax paid 67 per cent of net company tax.

While Australia has a comprehensive tax system, the effective tax base is somewhat narrow. Australia is highly reliant on direct taxation to raise revenue and, within those direct taxes, operates a highly progressive personal tax. This suggests that the public debt burden is likely to be highly concentrated. In terms of the public choice arguments made by economists such as James Buchanan, this simply increases the incentives for voters to borrow too much in the present.

\section{But this time it's different?}

Public debt that finances productivity-enhancing economic activity is likely to contribute to economic prosperity while public debt that does not finance productivity-enhancing economic activity is less likely to contribute to economic prosperity. Then Treasurer and now Prime Minister, Scott Morrison, attempted to make this distinction when he differentiated between 'good' debt and 'bad' debt in 2016 (Kohler, 2016). This observation would seem to imply that finding a relationship between public debt and economic prosperity should be a simple empirical exercise. This, however, has proven to be difficult (see, for example, the debate sparked by Reinhart \& Rogoff, 2010; and Herndon et al., 2014).

It is very likely that the methods empirical economists bring to bear and the coarse data available for analysis are unable to tease out the relationship - if any-between public debt and economic prosperity. Differentiating between 'good' and 'bad' debt would itself be entirely subjective. In any event, if Buchanan (1999b) is correct in arguing that all opportunity costs are both subjective and unobservable then broadscale macro-empirical techniques can never accurately measure the relationship between public debt and economic prosperity. Indeed, these techniques may not be able to measure many of the economic relationships for which economists routinely search.

It is possible, however, to conduct some thought experiments. For example, revealed policy preferences suggest that, historically, Australia has been a 'low-debt' economy. Political rhetoric - but not always action-suggests Australians prefer low debt to high debt and budget surpluses to budget deficits (or at least budgets that are close to being balanced). This rhetoric is bipartisan. No Australian Treasurer has argued 
that deficits persist for long periods or that high levels of debt are anything but temporary. Yet the recently released 2021 Intergenerational Report indicates that net debt will still be at 34.4 per cent of GDP in 2060-61. Similarly, the Intergenerational Report forecasts that the budget will not return to surplus in the next 40 years (The Treasury, 2021).

Like its predecessors, the 2021 Intergenerational Report is simply an extrapolation of current policy settings combined with some heroic assumptions about what may happen in the future to things such as migration, productivity and the terms of trade. Nonetheless, it paints a bleak picture of the current policy settings. Policy outcomes - that is, sustained long-term deficits and high levels of public debt—are inconsistent with stated policy goals and historical trends.

This suggests that either policy preferences have changed or a future government will attempt to balance the budget and pay down debt.

Stated policy preferences, however, have not changed. In his 2020 budget speech, Josh Frydenberg made this statement: 'Our economic and fiscal strategy sets out the path to grow the economy, stabilise debt, and then reduce it over time' (Frydenberg, 2020).

In April 2021, before the budget was brought down, the Australian Bureau of Statistics reported that unemployment was 5.5 per cent. By June 2021-the latest available data at the time this paper was written-unemployment was 4.9 per cent. By the government's own policy timetable, action towards 'stabilising gross and net debt as a share of the economy' should begin.

That argument, however, is predicated on the assumption that the Covid-19 crisis is over. It is true that unemployment has fallen well below 6 per cent, yet-again, at the time of writing-many Australians are in lockdown and the economy is not returning to normal (even as defined by the government).

Far more importantly, however, the post-Covid strategy set out in the 2020 budget assumes that post crisis, the economy will return to business as usual. That assumption underpins the forecasts in the Intergenerational Report, yet even those are inconsistent with the stated post-Covid strategy outlined in the 2020 budget.

Allen et al. (2020) argue that the economy is not likely to simply return to a businessas-usual trajectory. Their argument is that an economy cannot simply be switched off and on again like a machine. The economy is not simply a collection of various factors of production (land, labour and capital) that can be temporarily frozen in place and then unfrozen to continue as before as though nothing had happened. This, however, is the strategy that many governments around the world, including in Australia, have attempted. Individuals were ordered into lockdown, resulting in massive disruption to economic activity. This resulted in a massive expansion of 
central planning; governments around the world were making decisions as to what were the 'essential items' that consumers could buy, which stores would remain open and which would close, which employment categories were essential and whose employees could continue to work and which were not essential and whose workers had to stay at home. Central planning is known to be inefficient relative to a market economy (Mises, 1981; Hayek, 1945).

The counterargument is that this government intervention was a temporary response to a crisis. In wartime, governments have taken temporary control of the economy and economic growth has commenced at the end of the conflict. How, then, is this situation different? Allen et al. (2020) argue that the post-Covid situation is very different to previous economic crises, including war. During a war, the government does not attempt to stop economic activity from occurring; it attempts to redirect economic activity away from producing civilian consumer goods and towards producing military goods. During a 'conventional' economic crisis, the economy is already distorted and the government spends billions to rekindle economic activity. Government responses to the Covid-19 pandemic were to spend billions to stall the economy, and then keep it stalled-the expectation being that, after the crisis had passed, the economy would simply return to its previous level of activity.

If Allen et al.'s (2020) analysis is correct, the government's post-Covid fiscal strategy is doomed to failure. As Allen et al. (2020, p. 136) argue:

The secular mythology is that the economy will awaken blinking into the light, a little stiff and tired and hungover perhaps, carrying some extra debt around its middle to be sure, but otherwise good to go again, so long as we follow the public health plans.

This belief is wrong. That economy is gone. What we will return to is a different economy, with different preferences and uses of technology, new jobs and firms, and different patterns of trade and specialisation. The economic problem we face is not how to stimulate spending to get us back to January levels of GDP. We do not have a spending problem, because this situation was not caused by a loss of spending. What we face, rather, is a recoordination problem-what Friedrich Hayek called a 'knowledge problem' in figuring out how to re-create value.

\section{Conclusion}

Since 2007-08, when Australia had low levels of gross debt and negative net debt, the Australian economy has been buffeted by the GFC, bushfires and the Covid-19 pandemic. In response to these events, Australian governments have incurred large amounts of public debt and ramped up government spending. To be fair, this constitutes a 'mainstream' economic policy response to adverse economic shocks, yet the policy response to the pandemic was very different to that of previous crises. 
The government does not normally spend (borrowed) money to prevent economic activity from occurring. Whether or not that was a wise policy to pursue will be debated in the years to come.

What this paper has done is document the build-up of debt over the past 10 or so years. It has also debunked the notion that public debt is 'low'; it has especially debunked the notion that the debt burden is low. Debt is not 'cheap' simply because interest rates are low.

What remains to be explained is why policymakers appear to have abandoned what Buchanan and Wagner (2000) referred to as being 'the old-time fiscal religion'. This is the notion that the existence of public debt is a sign of public profligacy and that debt should be quickly paid down lest it impose a burden on future generations. This remains the rhetoric of Australian governments yet following the GFC, neither the Rudd-Gillard government nor the Abbott-Turnbull-Morrison government has shown any urgency in retiring public debt. Indeed, the Intergenerational Report shows that public debt will still not be paid down in 40 years.

It is not clear when or why the 'old-time fiscal religion' was abandoned. In late 2007, then opposition leader Kevin Rudd was able to campaign at an election with the slogan 'This sort of reckless spending must stop'. In the years since, there is no evidence that the spending has stopped; to the contrary, spending has increased and so, too, has public debt.

\section{References}

Allen, D., Berg, C., Davidson, S., Lane, A. \& Potts, J. (2020). Unfreeze: How to create a high growth economy after the pandemic. American Institute for Economic Research.

Australian Bureau of Statistics. (2021). Labour force, Australia (various issues). Australian Bureau of Statistics. Available from: www.abs.gov.au.

Barro, R. (1974). Are government bonds net wealth? Journal of Political Economy, 82(6), 1095-117. doi.org/10.1086/260266.

Buchanan, J. (1976). Barro on the Ricardian equivalence theorem. Journal of Political Economy, 84(2), 337-42. doi.org/10.1086/260436.

Buchanan, J. (1999a [1958]). Public principles of public debt. Liberty Fund.

Buchanan, J. (1999b [1969]). Cost and choice. Liberty Fund.

Buchanan, J. \& Wagner, R. (1967). Public debt in a democratic society. American Enterprise Institute. 
Buchanan, J. \& Wagner, R. (2000 [1977]). Democracy in deficit: The political legacy of Lord Keynes. Liberty Fund.

Cranston, M. (2020). Worried about Morrison's big debt? Relax. Australian Financial Review, 3 April.

Davidson, S. (2009). Tax and welfare. In K. Windschuttle, D.M. Jones \& R. Evans (eds), The Howard era. Quadrant Books.

Davidson, S. \& Heaney, R. (2012). Effective tax rates and the political cost hypothesis: A re-evaluation of Australian evidence. Australian Tax Forum, 27(1), 79-105.

Frydenberg, J. (2020). Budget speech 2020-21, 6 October. Available from: ministers. treasury.gov.au/ministers/josh-frydenberg-2018/speeches/budget-speech-2020-21.

Frydenberg, J. (2021). Budget speech 2021-22, 11 May. Available from: ministers.treasury. gov.au/ministers/josh-frydenberg-2018/speeches/budget-speech-2021-22.

Hayek, F. (1945). The use of knowledge in society. The American Economic Review, 35(4), 519-30.

Henry, K. (Henry Review). (2010). Australia's Future Tax System Review final report: Part one-Overview. Australia’s Future Tax System Review Panel, The Treasury. Available from: treasury.gov.au/review/the-australias-future-tax-system-review/final-report.

Herndon, T., Ash, M. \& Pollin, R. (2014). Does high public debt consistently stifle economic growth? A critique of Reinhart and Rogoff. Cambridge Journal of Economics, 38(2), 257-79. doi.org/10.1093/cje/bet075.

Kohler, A. (2016). Transcript of interview with the Hon. Scott Morrison MP Treasurer. Talking Finance, [podcast], 29 October. Parliament of Australia. Available from: parlinfo.aph. gov.au/parlInfo/search/display/display.w3p;query=Id:\%22media/pressrel/4907578\%22.

Mises, L. (1981 [1922]). Socialism. Liberty Fund.

Reinhart, C. \& Rogoff, K. (2010). Growth in a time of debt. The American Economic Review, 100(2), 573-78. doi.org/10.1257/aer.100.2.573.

The Treasury. (2021). 2021 Intergenerational Report. Australian Government. Available from: treasury.gov.au/publication/2021-intergenerational-report. 
This text is taken from Agenda, Volume 28 - Number 1, 2021 edited by William Coleman, published 2021 by ANU Press, The Australian National University, Canberra, Australia.

doi.org/10.22459/AG.28.01.2021.04 